\title{
The Effect of Ethnocentrism on Purchase Behavior of Domestic and Foreign Products
}

\author{
R. Hurriyati; Lisnawati \\ Faculty of Economic and Business Education, \\ Indonesia University of Education, \\ Bandung, Indonesia \\ ratih@upi.edu
}

\begin{abstract}
The purpose of this paper is to investigate national identity, cosmopolitanism and ethnocentrism in influencing the purchase behavior of domestic or foreign purchase behavior products in Indonesia. The method is descriptive verification, while the data analysis technique used is Structure Equation Model in 300 sample citizen of Indonesia. The results show that the model attitude of Indonesian citizens about national identity and cosmopolitanism thus forming ethnocentrism can be integrated to the measurement of purchase behavior of domestic or foreign purchase behavior products.
\end{abstract}

Key Word: consumer ethnocentric, purchase of domestic products, purchase of foreign products.

\section{INTRODUCTION}

ASEAN Economic Community a form ASEAN regional economic cooperation makes ASEAN as a single market, and production base which occurs commodity flow, services, investment and skilled personnel large and capital flows freer. The readiness of Indonesia in encountering the free trade must be in anticipation government in tackling the public purchase decisions that prefer foreign products compared to domestic products. Indonesia had the more than 220 million people with hundreds of tribes spread across different islands. Although it has differences in ethnicity and language, but there will definitely be the same character.

Indonesian people's dependence on foreign products will result in lack of economic a standalone Countries Indonesia is seen to have constraints on domestic products to compete with foreign products, the lack of awareness on the use of local products and feel luxurious when consuming foreign products will add to the increasing trend of Indonesian consumers choose products made overseas.

Intention and buy Indonesian products is a love expression of people of the nation of Indonesia, when the Indonesian consumers prefer products domestically made will indirectly increase the income of local entrepreneurs Indonesia even national income. Consumer behavior in choosing products domestically made or foreign product is influenced by various aspects of both around internal and external to the consumer. National identity, cosmopolitanism and ethnocentrism are some aspects that can influence.

\section{LITERATURE REVIEW}

\section{A. National Identity}

The definition of national identity is the extent to which a particular culture recognizes and identifies a set of elements that distinguish the focus of other cultures, with characterized aspects of complexity and a greater variety than others. [1] [2] [3] [4]

National identity very complicated and multi-dimensional matter. National identity formulated classical definition of the nation as a named human population sharing a historic territory, common myth and historical memories, a mass, public culture, common economy and common legal rights and duties for all members. [5] National identity according to Smith "involves some sense of political community, history, territory patria, citizenship common values and traditional. The conceptualization of the construct of national identity and national identity measurement scale has provided a new perspective emphasizes the characteristic of the "core" is unique, that a culture recognizes a separate set of various phenomena of religious, historical, and cultural [1] [2] [3] [4].

H1: National identity of Indonesian consumers had the significant effect on Consumer Ethnocentric.

\section{B. Cosmopolitanism}

Cosmopolitanism is a western notion that epitomizes the need social agents have to conceive of a political and cultural entity, larger than their own homeland, that would encompass all human beings on a global scale [7] he said that Cosmopolitanism is frequently conflated with the imperial inclinations of a historical period; a fact that stresses contradictory relationships with power.

Roland Robertson [8] is the first to reveal aware and awareness of one world the indicator of cosmopolitanism. Armin Nassehi pursues a similar argument, when he links cosmopolitanism to the Thomas theorem and thus to the selfdefinition and public reflexivity of trans national ways of life and situations, not only at the top but also at the bottom and in the middle of an emerging society of world citizens. [9]

H2: Cosmopolitanism of Indonesian consumers have a significant effect on Consumer Ethnocentric

\section{Customer Ethnocentrism}

Ethnocentrism is a basic attitude expressing the belief that one's own ethnic group or one's own culture is superior to other ethnic groups or cultures, and that one's cultural standards can be applied in a universal manner. ${ }^{(10)}$ Consumer ethnocentrism refer to the consumer's belief that buying a foreign products will potentially result in a domestic job's reduction and economic damage, state that consumer ethnocentrism is a behavioral pattern that is socialized during 
early-childhood years and is fairly inelastic to other product attributes, such as price and quality. [11]

Consumer ethnocentrism build upon a moral disposition, or have become a liability to support domestic product's even domestic product was considerably lower than foreign products. Empirical research on the impact of ethnocentric tendencies based on consumer attitudes had been made, developed, developing, mature, emerging and postconsumer market transition.[12] The dominant belief is that one's country and value that the country, represents are superior to other [13] consequently, ethnocentric consumers tend to bias against products from other countries, even when the domestic product alternatives are not available, consumer's ethnocentric alternated products of the same culture than the culture of different countries. [14]

H3: Ethnocentric attitude of Indonesian consumers have a significant effect on domestic purchase behavior

H4: Ethnocentric attitude of Indonesian consumers have a significant effect on foreign purchase behavior

\section{A. Customer Buying Behavior}

Increasingly rapid progress of time and the increasing standard of living has influenced a lot of things such as the requirements. Lifestyle, and consumers' desire to be a more diverse product, as consumer demand for a product can be fulfilled by a wide variety of similar products with a different brand, and advantages are sold in the market. It is forced consumers to be more critical in receiving incoming information regarding existing products as the stimulus well in decision-making.

According to Philips Kotler and Gary Armstrong. [15] states that there are four factors that influence consumer buying behavior that is: cultural factors, social factors, personal factors and psychological factors. Consumer in one country may have a positive effect toward another country, and how this positively affects their willingness to buy products from that country. [16]

\section{METHODS}

Based on the variables studied, the research method used in this research is descriptive and verification. Considering this research is descriptive and verification carried out through data collection in the field, the research method to be used is the explanatory survey. Sample of this research is 300 respondents. In addition, because this research is during the period of less than one year, then the method used is a cross sectional method.

Instruments in this study a questionnaire consisting of National identity, cosmopolitanism, consumer ethnocentric, domestics and foreign Purchase. To know National identity, cosmopolitanism, consumer ethnocentric, purchase domestics behavioral level and the level of foreign purchase behavior done directly by using a Likert Scale. The reason for choosing a Likert Scale as an instrument of psychological research as scale becomes very important. In Likert scale, each respondent was asked to give a statement about his perception of the National identity, cosmopolitanism, consumer ethnocentric. Domestics and foreign Purchase levels are very good, good, good enough, not good, and it was not good. The data source is anything that can provide information about the data. Based on the data source can be divided into two, namely the primary data and secondary data. In the study, the type of validity that is used is the construct validity that determines validity by way of correlating between the scores obtained on each item in the form of questions with a total score. The validity of the instrument in the questionnaire can be used to measure what should be measured, not the systematic error. Each factor in this study realiabel, the following is an operational variable in this study.

\begin{tabular}{|l|c|}
\multicolumn{2}{|c|}{ Table 1 Operational Measurement } \\
\begin{tabular}{|l|c|} 
Construct/Items & Composite \\
Realibility
\end{tabular} \\
\hline National Identity \\
Being a citizen of Indonesia is very meaningful for \\
me. \\
I am proud to be a citizen of Indonesia. \\
I have a strong interest in the State Indonesia. \\
I was part of the State Indonesia \\
\hline \begin{tabular}{l} 
Cosmopolitanism \\
I am glad be involved in different cultural \\
environments \\
I love to have relationships with people from \\
different cultures \\
I will be traveling go abroad for a certain period \\
\hline Ethnocentricity \\
I as a citizen of Indonesia felt it was important for me \\
to use products made in Indonesia \\
Products made in Indonesia is a prime choice for me \\
I as a citizen of Indonesia do not have to buy foreign- \\
made products \\
I buy foreign-made products only for products that \\
are not produced by the manufacturer Indonesia \\
I prefer chose product made in Indonesia than \\
foreign product, although with high prices
\end{tabular} \\
\hline $\begin{array}{l}\text { Domestic Purchase } \\
\text { I try to buy products made in Indonesia } \\
\text { I always make sure that the products I buy are made } \\
\text { products }\end{array}$ \\
I shop at retail stores that provide special marketing \\
program for local products
\end{tabular}

To examine the hypothesis that analysis method used in this quantitative study is the verification of analysis methods. In this study, for hypothesis test analysis techniques Structural Equation Model with the following structural Figure. 


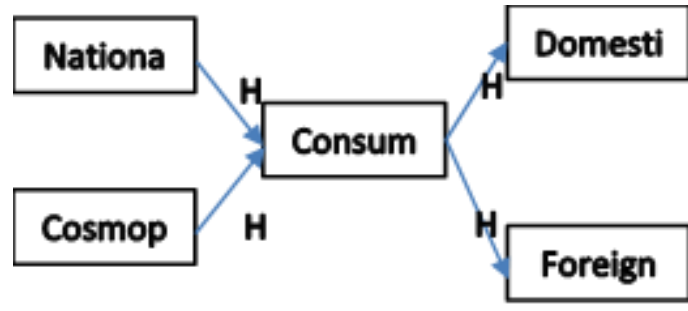

Figure. 1 Structural Equetional Model

\section{RESULT AND DISCUSSION}

Normality test results for a sample of 300 respondents, the critical ratio value of 11.737 . Normality test indicates abnormal data because it has multivariate critical ratio $11,737>2,58$, thus performed cleanup of data outliers. The results of data cleaning multivariate outlier obtained critical ratio of 1.093 $<2.58$, which means the normal data. 300 Data are outliers as many as 70 data so that the final data used in this research of 230 Data.

Test results a whole fitness model indicates that the model planned marginally to fit. Because after the match value of Chisquare test, $p$ value, and RMSEA than the reference value equation structural model the good results, respectively of them the value of chip-square p-value of $0.004<0.005$, and RMSEA value that is equal to 0.011 , assessment criteria better than the reference value (cut of value), it shows that the a whole conceptual structural equation models were designed based on goodness of fit meet the eligibility model (fit), which means in accordance with the conditions of empirical purchasing behavior through the processing results of SEM analysis AMOS 22 is presented in the following figure.

Figure 2. Structure Model Analysis

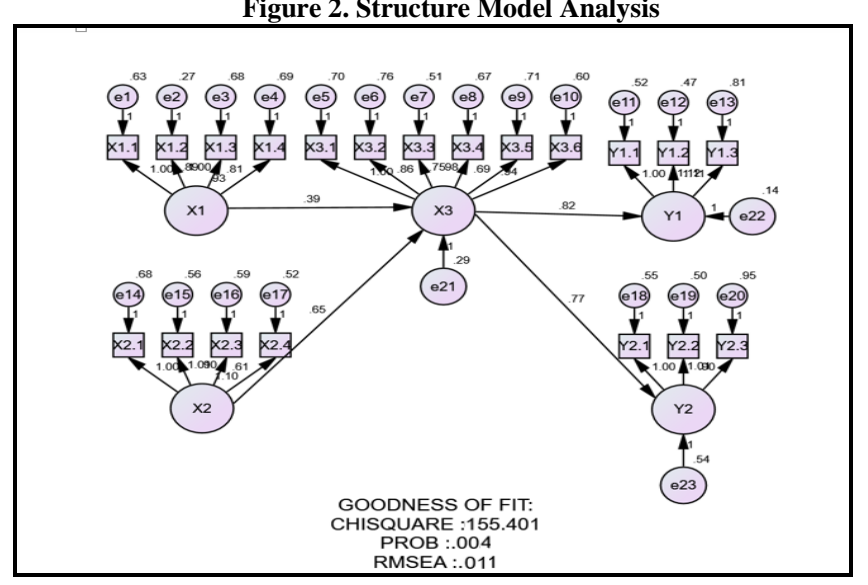

Based on the figure above indicates that the influences of respectively latent variable directly (standardize direct effect) are described as follows, variable national identity has a direct influence on the ethnocentric of 0.39 . Variable cosmopolitanism has a direct influence on the ethnocentric of 0.65 . Ethnocentricity variable has an influence on Domestic of Purchase of 0.82 , and ethnocentric have a direct influence on
Foreign Purchase of 0.77 . Purchasing behavior shaped by national identification, cosmopolitanism through ethnocentric.

As shown in this research methodology has limitations of the analysis of samples the state in this case Indonesia provide further insight into very specific conditions. In contrast to a similar study conducted by Abraham [17] about cosmopolitanism, national identity and ethnocentrism in Swedish explains that there is a negative influence between cosmopolitanism against ethnocentrism and negative influences between ethnocentric and purchase of foreign products. Difference between Indonesia countries as a developing country and Sweden as developed country is on the product availability in the country. In case of Sweden the majority of fulfillment products for the society is the result of goods made in their own country, while the Indonesian state is mostly imported goods from second countries such as china and japan

\section{REFFERENCES}

[1] Clark T. International Marketing and National Character : A Review and Proposal for an Integrative Theory. J Mark [Internet]. 1990;54(4):66-79.

[2] Huntington SP. American Identity: The Erosion of American National Interests. Foreign Aff [Internet]. 1997;76(5):28-49.

[3] Keillor BD, Hult GTM, Erffmeyer RC, Emin Babakus. NATID: The Development and Application of a National Identity Measure for Use in International Marketing. J Int Mark. 1996;4(2):57-73.

[4] Cui CC, Adams EI. National identity and NATID: An assessment in Yemen. Int Mark Rev. 2002;19(6):637-62.

[5] Smith AD. National Identity. Identity [Internet]. 1991;ZA3910:226.

[6] Keillor BD, Hult GTM. A five-country study of national identity research and practice. Int Mark Rev. 1999;16(1):65-82.

[7] Ribeiro GL. What is cosmopolitanism. Int Encycl Soc Behav [Internet]. 2001;4:2842-5.

[8] Robertson R. Roland Robertson. Globalizations [Internet]. 2014;11(4):447-59.

[9] Nassehi A. Die Theorie funktionaler Differenzierung im Horizont ihrer Kritik. Zeitschrift f\{ü\}r Soziologie [Internet]. 2004;33(2):98-116.

[10] Hooghe M. International Encyclopedia of the Social Science. International Encyclopedia of the Social Science. 2008. p. 1-5.

[11] Shimp T, Sharma S. Consumer Ethnocentrism: Construction and Validation of the CETSCALE. J Mark Res [Internet]. 1987;24(3):280-9.

[12] Sharma S, Shimp T a., Shin J. Consumer ethnocentrism: A test of antecedents and moderators. J Acad Mark Sci. 1995;23(1):26-37.

[13] Tae Lee K, Lee Y-I, Lee R. Economic nationalism and cosmopolitanism. Eur J Mark [Internet]. 2014;48(5/6):1133-58.

[14] Watson JJ, Wright K. Consumer ethnocentrism and attitudes toward domestic and foreign products. Eur J Mark. 2000;34(9/10):1149-66.

[15] Kotler P, Amstrong G. Fundamentos de Marketing [Internet]. Prentice Hall. 2008. 656 p.

[16] Oberecker EM, Diamantopoulos A. Consumers' Emotional Bonds with Foreign Countries: Does Consumer Affinity Affect Behavioral Intentions? J Int Mark. 2011;19(2):45-72.

[17] Abraha D, Radón A. The effect of cosmopolitanism , national identity and ethnocentrism on Swedish purchase behavior. 